\title{
Coagulation Factor Xa Stimulates Platelet-derived Growth Factor Release and Mitogenesis in Cultured Vascular Smooth Muscle Cells of Rat
}

\author{
Feng N. Ko, ${ }^{*}$ Ya C. Yang, ${ }^{\star}$ Shu C. Huang, ${ }^{\star}$ and Jonathan T. Ou ${ }^{\ddagger}$ \\ *Pharmacological Institute, College of Medicine, National Taiwan University, Taipei; and ${ }^{*}$ Department of Microbiology and \\ Immunology, Chang Gung College of Medicine and Technology, Taoyuan, Taiwan
}

\begin{abstract}
The mitogenic effect of activated coagulation factor $X$ (factor Xa) was examined in cultured aortic smooth muscle cells (VSMC) from Wistar-Kyoto rats (WKY). Factor Xa stimulated DNA synthesis and cell growth in VSMC, not through the phospholipase $\mathrm{C}$-protein kinase $\mathrm{C}$ pathway because increase of inositol monophosphate (IP) accumulation and intracellular $\mathrm{Ca}^{2+}$ concentration was not observed, but probably via the PDGF receptor tyrosine kinase pathway since the pathway's components, Ras, Raf-1, MAPK (both 42 and $44 \mathrm{kD}$ ), and the transcription factors, c-Fos and c-Jun, were activated. These appeared to be effected by the serine protease activity of factor $\mathrm{Xa}$, since in the presence of serine protease inhibitors such as PMSF, leupeptin, benzamidine, TAP anticoagulant, and TLCK, the latter three being specific inhibitors of the factor $\mathrm{Xa}$ active site, the effects were completely blocked. Anti-factor Xa mAb, 5224, which specifically negated the activity of factor $\mathrm{Xa}$, also inhibited completely the mitogenic effect of factor $\mathrm{Xa}$, but not that of thrombin. Addition of PDGF did not affect the effect of factor Xa, which, however, was inhibited by anti-PDGF-AB antibody. This observation and the activation of PDGF receptor tyrosine kinase pathway suggested that the factor $\mathrm{Xa}$ might exert its effect via PDGF-like function. Direct measurement confirmed that factor Xa stimulated the release of PDGF from VSMC. Factor Xa, therefore, exerts serine protease activity on VSMC, causing somehow the release of PDGF, that in turn acts on the PDGF receptor tyrosine kinase; the pathway is then turned on, leading eventually to DNA synthesis and cell proliferation. (J. Clin. Invest. 1996. 98:1493-1501.) Key words: factor Xa - mitogenesis • mitogen-activated protein kinase $\cdot$ platelet-derived growth factor • vascular smooth muscle cells
\end{abstract}

\section{Introduction}

Cardiovascular disease remains the chief cause of death in the world, and atherosclerosis, the principal cause of myocardial and cerebral infarction, accounts for the major cause of this disease (1). Proliferation of vascular smooth muscle cells

Address correspondence to Feng-Nien Ko, Ph.D., Pharmacological Institute, College of Medicine, National Taiwan University, No. 1, Jen-Ai Rd., Sect. 1, Taipei, Taiwan. Phone and FAX: 886-2-322-1742. Received for publication 16 February 1996 and accepted in revised form 25 June 1996.

J. Clin. Invest.

(C) The American Society for Clinical Investigation, Inc.

0021-9738/96/09/1493/09 \$2.00

Volume 98, Number 6, September 1996, 1493-1501
(VSMC) ${ }^{1}$ is an essential feature of the pathogenesis of atherosclerosis (2). In a normal artery most of the VSMC are confined to the tunica media of the vessel and the intima consists predominantly of endothelial cells. In atherosclerosis VSMC migrate into the intima and proliferate to form a fibrous cap over a lipid-rich core. In addition, VSMC proliferation is a well-documented cause of the remodeling of the vascular structure in a hypertensive state $(3,4)$ or of the restenosis that occurs in a large percentage of patients after coronary angioplasty (5). It is therefore of great interest to investigate the regulation mechanism of the proliferation of VSMC. There are a number of studies that reported evidences for the involvement of various vasoactive substances derived from vascular vessels in the modulation of VSMC growth (6-8).

Accumulation of fibrin in atherosclerotic lesions is well known and a link between coagulation and atherogenesis has long been suspected from clinicopathological studies $(9,10)$. A recent study also indicates that an increased ratio of fibrin II to fibrinogen correlates with more advanced lesions (9). Furthermore, thrombin, the final coagulation enzyme in the pathway leading to fibrin formation, is a well-established promotor of VSMC proliferation (11). By analogy with the paradigm of thrombin, earlier work suggested that factor Xa also participates in intracellular signaling and vascular cell activation mechanisms. Binding of factor Xa to human umbilical vein endothelial cells stimulates a concentration-dependent release of endothelial cell mitogen in a reaction unaffected by hirudin or by an antibody to factor V (12). More recent experiments further extended these observations by demonstrating that factor $\mathrm{Xa}$ acts as a potent mitogen for vascular rat aortic SMC (13). However, the cellular mechanism of factor Xa-induced VSMC proliferation, including whether or not the VSMC proliferation involves the activation of MAPK, has not been elucidated. Here, we report the results of a series of experiments in an attempt to elucidate the pathway factor Xa activates for VSMC proliferation. It becomes apparent that factor Xa exerts its effect indirectly via the release of PDGF that leads to the activation of MAPK, DNA synthesis and cell growth.

\section{Methods}

Reagents. PDGF-BB homodimer, polyclonal anti-human PDGF-AB antibody and monoclonal anti-phosphotyrosine antibody (Py20) were obtained from Upstate Biotechnology Inc. (Lake Placid, NY). A monoclonal antibody (mAb) against human factor Xa, 5224 was supplied by American Diagnostica Inc. (Greenwich, CT). Anti-murine recombinant $\mathrm{p} 42^{\mathrm{mapk}}$ (erk2), anti-rat MAPK (erk 1-CT), and anti-rat

1. Abbreviations used in this paper: MAPK, mitogen-activated protein kinase; MBP, myelin basic protein; rTAP, recombinant tick anticoagulant peptide; TLCK, N $\alpha$-p-tosyl-L-lysine chloromethyl ketone; VSMC, vascular smooth muscle cells. 
Raf-1 antibodies were purchased from Santa Cruz Biotechnology Inc. (Santa Cruz, CA). Anti-v-H-ras mAb, Y13-259, was obtained from Oncogene Science (Uniondale, NY). Benzamidine, N $\alpha$-p-tosyl-L-lysine chloromethyl ketone (TLCK), and myelin basic protein (MBP) were purchased from Sigma Chemical Company (St. Louis, MO). Protein G-Sepharose was obtained from Pharmacia LKB Biotechnology Inc. (Bromma, Sweden). $\left[{ }^{3} \mathrm{H}\right]$ Thymidine $(25 \mathrm{Ci} / \mathrm{mmol}),\left[\gamma^{3}{ }^{32} \mathrm{P}\right] \mathrm{ATP}(>5000$ $\mathrm{Ci} / \mathrm{mmol})$ and myo- $\left[2{ }^{3} \mathrm{H}\right]$ inositol $(17.1 \mathrm{Ci} / \mathrm{mmol})$ were purchased from Amersham (Buckinghamshire, UK). [ $\left.{ }^{32} \mathrm{P}\right]$ Phosphorus was obtained from ICN (Costa Mesa, CA). Factor Xa, factor X, thrombin, aprotinin, leupeptin, PMSF and hirudin (recombinant) were purchased from Calbiochem (La Jolla, CA). Recombinant tick anticoagulant peptide (rTAP) originally isolated from Ornithodoros moubata was supplied by Merck Sharp \& Dohme Res. Lab. (Rahway, NJ). All cell culture reagents were purchased from GIBCO BRL (Grand Island, NY). All other chemicals were reagent grade.

Chromogenic assay of mAb5224 activity. The inhibitory activity of mAb5224 on the function of factor $\mathrm{Xa}$, its antigen, was also measured chromogenically with S-2222 (Chromogenix), a chromogenic substrate. $10 \mu \mathrm{l}$ of factor Xa (final concentration $20 \mathrm{nM}$ ) were added into $0.9 \mathrm{ml}$ of the buffer (50 mM Tris- $\mathrm{HCl}, \mathrm{pH} 8.2,0.1 \% \mathrm{BSA})$ that contained various amounts of mAb5224 (concentration ranged from 0 to $50 \mu \mathrm{g} / \mathrm{ml}$ ), and the mixture was incubated at $37^{\circ} \mathrm{C}$ for $10 \mathrm{~min} .50$ $\mu \mathrm{g}$ (in $20 \mu \mathrm{l}$ of volume) of the substrate, S-2222, were then added, and the absorbance was measured at $405 \mathrm{~nm}$.

Cell culture. Medial explants were dissected from freshly harvested rat aortic strips and plated in 100-mm Petri dishes (14). Aortic SMCs (VSMC) from explants were grown in DME containing fetal calf serum (FCS, 10\%), penicillin $\mathrm{G}(100 \mathrm{U} / \mathrm{ml})$ and streptomycin $(100 \mu \mathrm{g} / \mathrm{ml})$, at $37^{\circ} \mathrm{C}$ in a humidified, $5 \% \mathrm{CO}_{2}$ incubator. Explant-derived cells were initially treated with $0.1 \%$ trypsin- 4 mM EDTA for 3 min at $37^{\circ} \mathrm{C}$ and hereafter, the passage was made conventionally. Cells from passages 5 through 15 were used for all growth studies. The cells were characterized as smooth muscle cells by morphology and immunostaining with $\mathrm{mAb}$ specific for smooth muscle $\alpha$-actin (CGA-7). For experiments, cells were subcultured into 24 -well plates in a medium containing $10 \%$ FCS for $24 \mathrm{~h}$ with an initial density of $5 \times 10^{4}$ cells per well. The cells were then starved for serum for $48 \mathrm{~h}$ to render them quiescent.

$\left[{ }^{3} \mathrm{H}\right]$ Thymidine incorporation. Incorporation of $\left[{ }^{3} \mathrm{H}\right]$ thymidine into VSMC was measured with minor modifications as described previously (15). Quiescent cells were incubated with factor Xa in $1 \mathrm{ml}$ FCS-free DME at $37^{\circ} \mathrm{C}$ for $20 \mathrm{~h}$, when $[3 \mathrm{H}]$ thymidine $(1 \mu \mathrm{Ci} / \mathrm{ml})$ was added for pulse labeling. The cells were further incubated for an additional $4 \mathrm{~h}$, and then washed twice with $1 \mathrm{ml}$ of phosphate-buffered saline (PBS). The cells were treated with $10 \%$ trichloroacetic acid (TCA) to precipitate the acid-insoluble material, from which the DNA was extracted with $0.1 \mathrm{~N} \mathrm{NaOH}$. The DNA was collected on a Whatman GF/B filter and washed twice with $5 \mathrm{ml}$ ice-cold PBS. The filter was then cut and shaken in $3.5 \mathrm{ml}$ scintillation fluid for $24 \mathrm{~h}$ before counting in a liquid scintillation counter.

Cell counts. To determine the effect of factor Xa on cell growth, cells were seeded in 6-well plates $\left(2 \times 10^{4}\right.$ cells/well $)$ and cultured for $48 \mathrm{~h}$ in DME supplemented with FCS $(10 \%)$. Cells were then cultured in FCS-free medium for $48 \mathrm{~h}$ to induce quiescence. The quiescent cells were incubated for 1 or $2 \mathrm{~d}$ in medium containing various agents. The culture medium was replaced with fresh one daily and cell numbers were determined by counting with a hemocytometer the adherent cells that had been dissociated with trypsin/EDTA. Triplicate counts were taken for each well, and quadruplicate wells were used for each determination.

Protein synthesis. Serum-starved cells were cultured in medium containing stimulating agent for $20 \mathrm{~h}$. Then, cells were incubated for $4 \mathrm{~h}$ in freshly prepared medium that contained $\left[{ }^{3} \mathrm{H}\right]$ leucine $(1 \mu \mathrm{Ci} / \mathrm{ml})$ for the measurement of protein synthesis in terms of $\left[{ }^{3} \mathrm{H}\right]$ leucine incorporation. The cells were harvested and homogenized with a sonicator in $25 \mathrm{mM}$ PBS containing $1 \mathrm{mM}$ EDTA. The homogenate was treated with ice-cold TCA (5\%). The precipitate was washed with the TCA solution and dissolved in $1 \mathrm{ml}$ of $0.5 \mathrm{~N} \mathrm{NaOH}$ solution. The radioactivity was measured in a liquid scintillation counter.

Flow cytometry. To estimate the proportion of cells at various stages in different phases of the cell cycle, cellular DNA content was measured by flow cytometry (16). Cells were trypsinized, centrifuged at 1,500 rpm for $3 \mathrm{~min}$, washed with PBS, and then cleared of RNA with RNase A $(0.1 \mathrm{mg} / \mathrm{ml})$. The DNA was stained with propidium iodide $(40 \mu \mathrm{g} / \mathrm{ml})$ at $37^{\circ} \mathrm{C}$ for $30 \mathrm{~min}$, and analyzed with a FACstar cytofluorometer (Becton-Dickinson; San Jose, CA), with excitation at $488 \mathrm{~nm}$ and emission at $585 \mathrm{~nm}$.

$\left[{ }^{3} H\right]$ Inositol phosphate accumulation. Cells for estimation of inositol phospholipid hydrolysis were grown in 12-well plates. At confluence, cell monolayers were loaded with $\left[{ }^{3} \mathrm{H}\right]$ myo-inositol $(5 \mu \mathrm{Ci} / \mathrm{ml})$ for $24 \mathrm{~h}$ in inositol-free DME. The labeled cells were then washed twice with KHS solution (composition in $\mathrm{mM}$ : $\mathrm{NaCl} 117.5, \mathrm{KCl} 5.4$, $\mathrm{NaH}_{2} \mathrm{PO}_{4} 1.2, \mathrm{NaHCO}_{3} 25.0, \mathrm{CaCl}_{2} 2.5, \mathrm{MgSO}_{4} 1.2$, glucose 5.5 and Hepes 25.0; $\mathrm{pH} 7.4$ ) and incubated for $15 \mathrm{~min}$ in the presence of 10 $\mathrm{mM} \mathrm{LiCl}$. Factor Xa was then added and incubation continued for $1 \mathrm{~h}$. The incubation was terminated with the addition of a stopping buffer $(0.1 \mathrm{~N} \mathrm{NaOH}+0.4 \%$ EDTA) and then $0.1 \mathrm{~N} \mathrm{HCl}(1: 1 \mathrm{vol} / \mathrm{vol})$. Cells were left for a minimum of $30 \mathrm{~min}$ at $-20^{\circ} \mathrm{C}$, and total $\left[{ }^{3} \mathrm{H}\right]$ inositol phosphate was isolated by anion-exchange chromatography as described by Alexander et al. (17). The radioactivity was determined in a scintillation counter.

Measurement of intracellular $\mathrm{Ca}^{2+}$ level. VSMC were cultured on a glass coverslip and incubated in a medium containing $5 \mu \mathrm{M}$ of fura2/AM, a $\mathrm{Ca}^{2+}$ indicator, for $45 \mathrm{~min}$ at $37^{\circ} \mathrm{C}$. The loaded coverslip was then mounted in a specially designed holder which enabled the coverslip to be positioned diagonally in a polymethacrylate cuvette. Each cuvette contained $2.4 \mathrm{ml}$ of KHS solution, to which $100 \mu \mathrm{l}$ of the drug were added, and the fluorescence was measured at $37^{\circ} \mathrm{C}$ with a spectrophotometer (CAF-100; Jasco, Japan). The excitation wavelengths were 340 and $380 \mathrm{~nm}$, and the emission wavelength was $510 \mathrm{~nm}$. The ratio of the excitation fluorescence at $340 \mathrm{~nm}$ (F340) to that at $380 \mathrm{~nm}$ (F380) was calculated from illumination periods and referred to as $\mathrm{R}_{340 / 380}$. The ratio was used to estimate the intracellular $\mathrm{Ca}^{2+}$ concentration as described by Grynkiewicz et al. (18).

$M A P K$ assay. Quiescent VSMC were stimulated with factor Xa for the indicated time. After washing once with ice-cold PBS, the cells were lysed with ice-cold lysis buffer (consisted of, in mM, Hepes 20, $\beta$-glycerophosphate $80, \mathrm{Na}_{3} \mathrm{VO}_{4}$ 0.2, dithiothreitol 2, EGTA 10, phenylmethylsulfonyl fluoride [PMSF] 0.1, and EDTA 2). The cells were then sonicated for $5 \mathrm{~s}$ and centrifuged at $14,000 \mathrm{~g}$ at $4^{\circ} \mathrm{C}$ for $30 \mathrm{~min}$ (Beckman TL-100). The supernatant was used as the source of MAPK. Aliquots containing an equal amount of protein $(2 \mathrm{mg})$ were used for immunoprecipitation. The kinase was assayed using ${ }^{32} \mathrm{P}$ phosphorylation of MBP as a measurement of MAPK activity as described by Morinelli et al. (19). The reaction mixture (containing, in $\mathrm{mM}$ unless otherwise noted, $\beta$-glycerophosphate 5 , Hepes $20, \mathrm{MgCl}_{2}$ 10, dithiothreitol 2, $0.02 \%$ Triton $\mathrm{X}-100, \mathrm{Na}_{3} \mathrm{VO}_{4} \mathrm{0.1}$, ATP 0.05 , as well as [ $\left.\gamma^{-32} \mathrm{P}\right]$ ATP $5 \mu \mathrm{Ci}$ and MBP $1 \mathrm{mg} / \mathrm{ml}$ ) was incubated with $20 \mu \mathrm{l}$ of the protein sample for $30 \mathrm{~min}$ at $25^{\circ} \mathrm{C}$. Incorporation of ${ }^{32} \mathrm{P}$ was measured as described by Erikson et al. (20).

Immunoprecipitation and immunoblot analysis. VSMC treated with factor Xa as described above were lysed in $1 \mathrm{ml}$ of the immunoprecipitation buffer containing $20 \mathrm{mM}$ Tris- $\mathrm{HCl}, \mathrm{pH}$ 7.5, 2 mM EDTA, 40 $\mathrm{mM}$ sodium pyrophosphate, $50 \mathrm{mM} \mathrm{NaCl}, 100 \mu \mathrm{M} \mathrm{Na} \mathrm{VO}_{4}$ and $1 \%$ Triton X-100, and centrifuged at $14,000 \mathrm{~g}$ for $10 \mathrm{~min}$. The supernatant was then incubated with $2 \mu \mathrm{g} / \mathrm{ml}$ of anti-rat MAPK at $4^{\circ} \mathrm{C}$ for $2 \mathrm{~h}$. All immune complexes were pre-cleared by incubation with protein $\mathrm{G}$-agarose (Gamma Bind G; Genex Corp., Gaithersburg, MD) at $4^{\circ} \mathrm{C}$ for $1 \mathrm{~h}$. The immunoprecipitates were washed three times with $1 \mathrm{ml}$ immunoprecipitation buffer and treated with $20 \mu \mathrm{l}$ Laemmli's sample buffer. The proteins were separated by $10 \%$ SDS-PAGE, and subjected to Western blot analysis using $100 \mu \mathrm{l}$ anti-phosphotyrosine mAb (Py20) as the primary antibody and goat anti-mouse IgG conjugated to alkaline phosphatase (200-fold dilution) as the secondary antibody. The blot was developed by adding the alkaline phosphatase substrate 
5-bromo-4-chloro-3-indolyl-phosphate/nitroblue tetrazolium (BCIP/ NBT) in $0.1 \mathrm{M}$ Tris ( $\mathrm{pH} \mathrm{8.9)}$ ) for $30 \mathrm{~min}$.

Analysis of Ras-bound GTP and GDP. Quiescent cells were labeled with $0.2 \mathrm{mCi} / \mathrm{ml}\left[{ }^{32} \mathrm{P}\right]$ phosphorus in phosphate-free DME for 4 $\mathrm{h}$, and stimulated with factor Xa for $2 \mathrm{~min}$. The cells were lysed in Triton $\mathrm{X}-114$ buffer containing $50 \mathrm{mM}$ Hepes-NaOH (pH 7.4), 1\% Triton X-114, $100 \mathrm{mM} \mathrm{NaCl}, 5 \mathrm{mM} \mathrm{MgCl}, 1 \mathrm{mM}$ PMSF, $100 \mu \mathrm{M}$ GTP, $100 \mu \mathrm{M}$ GDP, $1 \mathrm{mM}$ ATP, $20 \mu \mathrm{g} / \mathrm{ml}$ aprotinin, $1 \mathrm{mM}$ sodium pyrophosphate, and $1 \mathrm{mM} \mathrm{Na} \mathrm{VO}_{4}$. The phosphate inhibitors were included in the buffer to improve the recovery of GTP form of Ras (21). Membrane-bound Ras was recovered by detergent phase splitting (22) and immunoprecipitation with an anti-p21 ${ }^{\text {ras }} \mathrm{mAb}$ (Y13-259) with the aid of protein G-Sepharose. The immune complex was washed with washing buffer containing $50 \mathrm{mM}$ Hepes- $\mathrm{NaOH}(\mathrm{pH}$ 7.4), $5 \mathrm{mM} \mathrm{MgCl}_{2}, 50 \mathrm{mM} \mathrm{NaCl}, 1 \mathrm{mM}$ sodium pyrophosphate, $1 \mathrm{mM}$ $\mathrm{Na}_{3} \mathrm{VO}_{4}$ and $0.1 \%$ Triton X-100. Guanine nucleotide bound to Ras was eluted and analyzed by thin layer chromatography on a polyethyleneimine-cellulose plate. The result was expressed as GTP/(GTP + GDP) $\times 100(\%)$, which indicated the amount of GTP-bound Ras before and after an exposure to factor Xa.

$p 74^{\text {raf-1 }}$ activity assay. Quiescent VSMC were stimulated with factor Xa for the indicated time, and washed with ice-cold PBS. Cells were scraped and lysed in $1 \mathrm{ml}$ of lysis buffer containing $50 \mathrm{mM}$ Tris$\mathrm{HCl}$ (pH 7.5), $150 \mathrm{mM} \mathrm{NaCl}, 2$ mM EDTA, 2 mM EGTA, $40 \mathrm{mM} \beta$-glycerophosphate, $50 \mathrm{mM} \mathrm{NaF}, 10 \mathrm{mM}$ sodium pyrophosphate, $200 \mu \mathrm{M}$ $\mathrm{Na}_{3} \mathrm{VO}_{4}, 25 \mu \mathrm{g} / \mathrm{ml}$ leupeptin, $200 \mu \mathrm{g} / \mathrm{ml}$ aprotinin, $1 \mathrm{mM}$ PMSF, $10 \%$ glycerol and $1 \%$ Triton X-100. The cell lysate was centrifuged at $14,000 \mathrm{~g}$ for $10 \mathrm{~min}$. Raf-1 protein was immunoprecipitated with $\mathrm{COOH}$-terminal-specific polyclonal antibody as described by Sozeri et al. (23) and incubated for $30 \mathrm{~min}$ at $25^{\circ} \mathrm{C}$ in $20 \mu \mathrm{l}$ of kinase buffer containing $10 \mathrm{mM}$ Tris- $\mathrm{HCl}$ ( $\mathrm{pH} 7.5), 10 \mathrm{mM} \mathrm{MnCl}_{2}, 150 \mathrm{mM} \mathrm{NaCl}, 2$ $\mathrm{mM}$ dithiothreitol, $1 \%$ Triton X-100, $1 \mu \mathrm{M}$ ATP, $0.2 \mu \mathrm{Ci}\left[\gamma^{-}{ }^{32} \mathrm{P}\right] \mathrm{ATP}$ and $0.8 \mu \mathrm{g}$ of recombinant glutathione-S-transferase-MAPKK. The kinase reaction was stopped by the addition of Laemmli's sample buffer. The sample was electrophoresed in $7.5 \%$ SDS-PAGE and autoradiographed.

Nuclear extract preparation and Western blotting. Cells $\left(2 \times 10^{7}\right)$ were collected in PBS and pelleted at $500 \mathrm{~g}$ for $5 \mathrm{~min}$ at $4^{\circ} \mathrm{C}$. The cells were lysed in $1 \mathrm{ml}$ of lysis buffer $(10 \mathrm{mM}$ Tris- $\mathrm{HCl}, 140 \mathrm{mM} \mathrm{KCl}, 5$ $\mathrm{mM} \mathrm{MgCl}_{2}, 1 \mathrm{mM}$ DTT, $\mathrm{pH}$ 7.9) containing freshly added protease inhibitors $(0.25 \mathrm{mM}$ PMSF and $2.5 \mu \mathrm{g}$ each of antipain, leupeptin, chymostatin and pepstatin A). After the lysis, $1 \mathrm{ml}$ of lysis buffer containing 1\% Nonidet P-40 was then added and the cells were further incubated for $5 \mathrm{~min}$ on ice. The nuclei were collected by centrifuging at $500 \mathrm{~g}$ for $5 \mathrm{~min}$ at $4^{\circ} \mathrm{C}$, washed with $1 \mathrm{ml}$ of cold buffer $(20 \mathrm{mM}$ Tris- $\mathrm{HCl}, 20 \%$ glycerol, $140 \mathrm{mM} \mathrm{KCl}, 10 \mathrm{mM} \mathrm{MgCl} 2,1 \mathrm{mM}$ DTT) and resuspended in $500 \mu \mathrm{l}$ of nuclear extraction buffer $(0.35 \mathrm{M} \mathrm{NaCl}$, $5 \mathrm{mM}$ EDTA, $1 \mathrm{mM}$ DTT, $10 \mathrm{mM}$ Hepes, $\mathrm{pH}$ 7.5) containing the above mentioned protease inhibitors. After $30 \mathrm{~min}$ at $4^{\circ} \mathrm{C}$ with periodic stirring, the mixture was centrifuged at $10,000 \mathrm{~g}$ for $15 \mathrm{~min}$ and the supernatant containing the nuclear extract was used for Western blotting. After $8 \%$ SDS-PAGE, the proteins were transferred to a nitrocellulose paper. The paper was soaked in 5\% nonfat milk for 45 min to decrease nonspecific binding, and then allowed to react with specific antibody dissolved in 5\% nonfat milk for $45 \mathrm{~min}$. The membrane was washed twice, each time for $7 \mathrm{~min}$, with Tris-buffered saline (10 mM Tris- $\mathrm{HCl}, 150 \mathrm{mM} \mathrm{NaCl}, \mathrm{pH} 8.0)$, containing $0.05 \%$ Tween 20, and then incubated with horseradish-peroxidase-conjugated goat anti-rabbit (for Fos and Jun) antibody at 1:3000 dilution in $5 \%$ non-fat milk for $30 \mathrm{~min}$. Next, the membrane was washed three times, each time for $5 \mathrm{~min}$, with Tris-buffered saline containing $0.05 \%$ Tween 20, and once for $5 \mathrm{~min}$ with Tris-buffered saline. Signals were detected by exposure to $\mathrm{x}$-ray film.

Determination of PDGF content in conditioned medium. Confluent cultures of VSMC in 35-mm Petri dishes were washed with PBS and placed in fresh serum-free DME. Factor Xa was added to dishes for indicated times. Conditioned medium was centrifuged at 4,000 $\mathrm{g}$ for $10 \mathrm{~min}$ to remove debris and stored at $4^{\circ} \mathrm{C}$. The medium was used for assay within $7 \mathrm{~d}$. The concentration of PDGF in the conditioned medium was determined using an enzyme immunoassay (EIA) for PDGF, as described by Kumar et al. (24). Purified human PDGF was used to construct a standard curve, with which a regression line of the best fit from the linear portion of the standard curve was determined. The amount of PDGF in conditioned medium was expressed as ng/ $10^{6}$ cells of PDGF.

Data analysis. The experimental results were expressed as the mean \pm SEM and accompanied by the number ( $n$ ) of observations. A one-way Analysis of Variance (ANOVA) was used for multiple comparison. If there was a significant variation between treatment groups, Student's $t$-test was applied. A $P$ value of $<0.05$ was considered to be statistically significant.

\section{Results}

Effect of factor Xa on $\left[{ }^{3} \mathrm{H}\right]$ thymidine incorporation in VSMC. As shown in Fig. $1,\left[{ }^{3} \mathrm{H}\right]$ thymidine incorporation steadily increased as the dose of factor Xa increased, reaching a plateau at $6 \mathrm{nM}$ (this amount was used hereafter unless otherwise mentioned) with an $\mathrm{EC}_{50}$ value of $0.46 \pm 0.03 \mathrm{nM}$. In contrast, factor $\mathrm{X}(0.02-20 \mathrm{nM})$ stimulated little [ $\left.{ }^{3} \mathrm{H}\right]$ thymidine incorporation even at a dose as high as $20 \mathrm{nM}$. Similarly, when FCS (1\%), ADP $(1 \mu \mathrm{M})$, angiotensin II $(1 \mathrm{nM})$, PDGF $(0.2 \mathrm{ng} / \mathrm{ml})$, or the supernatant $(50 \mu \mathrm{l})$ of collagen $(0.5 \mu \mathrm{g} / \mathrm{ml})$-challenged human platelet suspension was added, no significant $\left[{ }^{3} \mathrm{H}\right]$ thymidine incorporation $(20 \pm 9,23 \pm 8,24 \pm 8,15 \pm 9$, and $24 \pm 6 \%$ increase over the basal level, respectively; $n=4-6$ ) was observed. However, these factors except PDGF markedly potentiated VSMC for the factor Xa-stimulated DNA synthesis (Fig. 2).

The factor Xa-induced $\left[{ }^{3} \mathrm{H}\right]$ thymidine incorporation was inhibited by serine protease inhibitors, PMSF and leupeptin, but not by aprotinin (Fig. 3). The similar inhibitory effect on factor Xa (6 $\mathrm{nM})$-induced DNA synthesis was also obtained with benzamidine, TLCK and rTAP, all specific inhibitors of the factor $\mathrm{Xa}$ active site with $\mathrm{IC}_{50}$ values $3.6 \pm 0.9 \mu \mathrm{M}, 3.3 \pm 0.1$ $\mathrm{mM}$, and 4.6 $\pm 0.1 \mathrm{nM}$, respectively. Furthermore, mAb5224, an anti-factor $\mathrm{Xa} \mathrm{mAb}$, also markedly inhibited DNA synthesis induced by factor Xa (Fig. 3) but not that caused by thrombin (0.01-3 U/ml, data not shown). Chromogenic test indicated

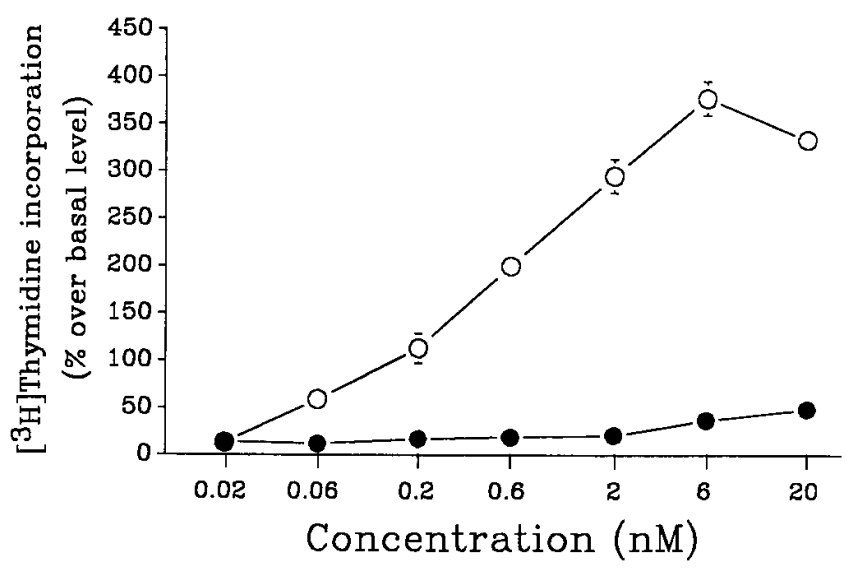

Figure 1. Increase in $\left[{ }^{3} \mathrm{H}\right]$ thymidine incorporation into VSMC stimulated with factor $\mathrm{X}$ or factor $\mathrm{Xa} .\left[{ }^{3} \mathrm{H}\right]$ Thymidine was added $20 \mathrm{~h}$ after the exposure of quiescent cells to factor $\mathrm{X}(\bullet)$ or $\mathrm{Xa}(\mathrm{O})$ and incubation was continued for another $4 \mathrm{~h}$. Basal $\left[{ }^{3} \mathrm{H}\right]$ thymidine incorporation was $104 \pm 12 \mathrm{dpm}$. Data are expressed as the mean $\pm \operatorname{SEM}(n=6$, each point in quadruplicate). 


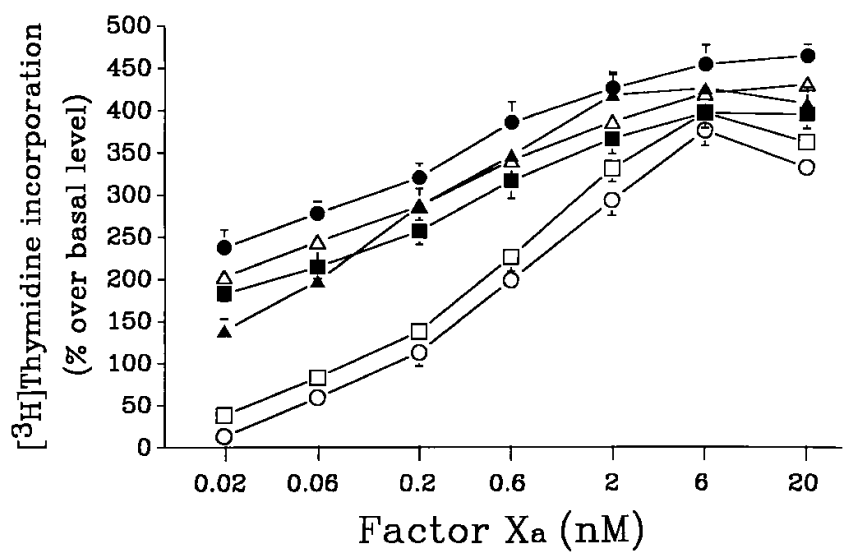

Figure 2. Potentiation of VSMC for $\left[{ }^{3} \mathrm{H}\right]$ thymidine incorporation stimulated with factor Xa. Quiescent cells were stimulated with factor $\mathrm{Xa}$ in the presence of saline $(\mathrm{O}$, control), FCS $(1 \%, \bullet), \operatorname{ADP}(1 \mu \mathrm{M}$, $\triangle)$, angiotensin II ( $1 \mathrm{nM}, \mathbf{\Delta})$, PDGF $(0.2 \mathrm{ng} / \mathrm{ml}, \square)$, or the supernatant from collagen $(0.5 \mu \mathrm{g} / \mathrm{ml})$-challenged human platelet suspension $(50 \mu \mathrm{l}, \boldsymbol{\square})$ for $24 \mathrm{~h}$. Labeling of $\left[{ }^{3} \mathrm{H}\right]$ thymidine was carried out as described in the legend to Fig. 1. Basal $\left[{ }^{3} \mathrm{H}\right]$ thymidine incorporation was $113 \pm 15 \mathrm{dpm}$. Data are presented as the mean \pm SEM $(n=4-6$, each assayed in quadruplicate). The results obtained in the presence of FCS, ADP, angiotensin II, and the supernatant from collagen-challenged human platelet suspension, respectively, are significantly different from that of control $(\bigcirc)$.

that mAb5224 also inhibited the enzyme activity of factor Xa $(20 \mathrm{nM})$ in a concentration-dependent manner with an $\mathrm{IC}_{50}$ of $12.5 \pm 2.3 \mu \mathrm{g} / \mathrm{ml}(n=6)$. On the other hand, hirudin $(0.3 \mathrm{U} / \mathrm{ml})$, a highly specific thrombin inhibitor, inhibited DNA synthesis induced by thrombin $(0.3 \mathrm{U} / \mathrm{ml}$ ) (from $379 \pm 54$ down to $6 \pm 4 \%$ increase over the basal level, $n=5)$ as expected but not that caused by factor Xa ( $6 \mathrm{nM} ; 397 \pm 18$ vs. $412 \pm 29 \%$ increase over the basal level, $n=4)$. Other inhibitors, such as genistein, lav-

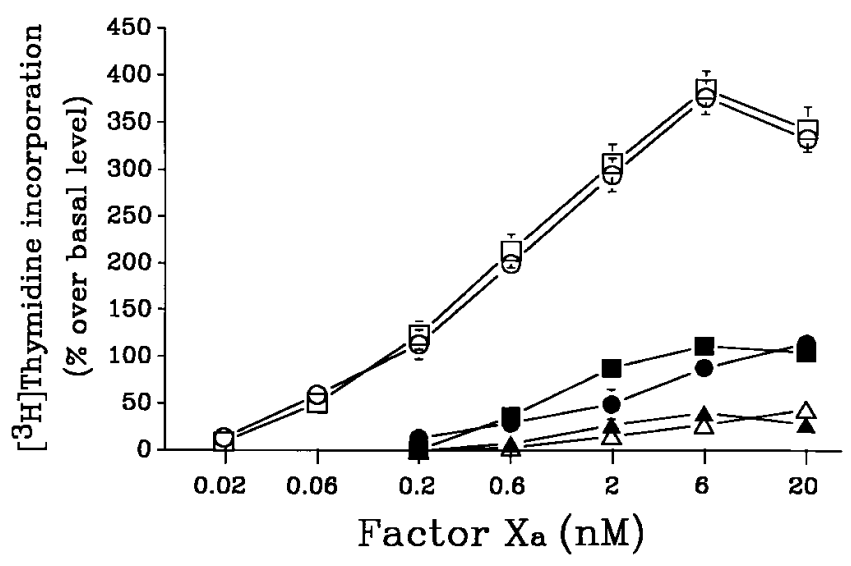

Figure 3. Inhibition of factor Xa-induced $\left[{ }^{3} \mathrm{H}\right]$ thymidine incorporation by PMSF, leupeptin, aprotinin and mAb5224. Quiescent cells were stimulated with factor $\mathrm{Xa}$ in the absence $(\mathrm{O}$, control) or presence of PMSF $(10 \mu \mathrm{M}, \bullet ; 30 \mu \mathrm{M}, \triangle)$, leupeptin $(1 \mu \mathrm{g} / \mathrm{ml}, \mathbf{\Lambda})$, aproti$\operatorname{nin}(2.5 \mu \mathrm{g} / \mathrm{ml}, \square)$ or mAb5224 $(2.5 \mu \mathrm{g} / \mathrm{ml}, \boldsymbol{\square})$ for $24 \mathrm{~h}$. See the legend of Fig. 1 for the labeling with $\left[{ }^{3} \mathrm{H}\right]$ thymidine. Basal $\left[{ }^{3} \mathrm{H}\right]$ thymidine incorporation was $121 \pm 14 \mathrm{dpm}$. Data are the mean $\pm \operatorname{SEM}(n=5-6$, each point assayed in quadruplicate). Each data point in the presence of PMSF, leupeptin or mAb5224 is significantly different from control $(\bigcirc)$
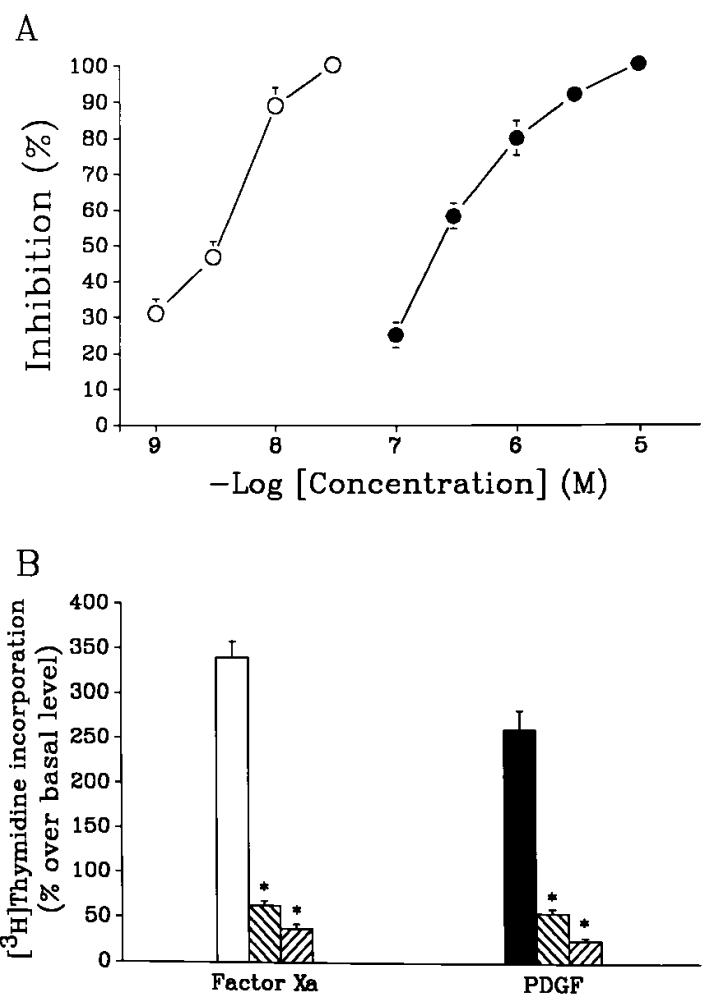

Figure 4. Inhibition of factor Xa-stimulated $\left[{ }^{3} \mathrm{H}\right]$ thymidine incorporation by lavendustin $\mathrm{A}$, genistein, tyrphostin 9, and anti-human PDGF-AB antibody. In $A$, quiescent cells were stimulated with factor $\mathrm{Xa}(6 \mathrm{nM})$ in the absence (control) or presence of various concentrations of lavendustin A $(\bigcirc)$ or genistein $(\bullet)$ for $24 \mathrm{~h}$. In $B$, cells were stimulated with factor Xa $(6 \mathrm{nM}, \square)$ or PDGF $(2 \mathrm{ng} / \mathrm{ml}, \mathbf{\square})$, in the absence (control) or presence of tyrphostin $9(0.1 \mu \mathrm{M}, \mathbb{\mathbb { N }})$ or anti-human PDGF-AB antibody $(5 \mu \mathrm{g} / \mathrm{ml}, \mathbb{C})$ for $24 \mathrm{~h} .\left[{ }^{3} \mathrm{H}\right]$ Thymidine was added $20 \mathrm{~h}$ after the exposure of the quiescent cells to factor Xa or PDGF and incubation was continued for another $4 \mathrm{~h}$. Basal $\left[{ }^{3} \mathrm{H}\right]$ thymidine incorporation was $115 \pm 11 \mathrm{dpm}$. Data are expressed in the mean \pm $\operatorname{SEM}(n=4-6$, each assayed in quadruplicate). $* P<0.001$ as compared with the respective control.

endustin A, tyrphostin 9 and a polyclonal anti-human PDGF-AB antibody, also inhibited factor Xa-stimulated DNA synthesis in VSMC (Fig. 4). The $\mathrm{IC}_{50}$ of lavendustin A or genistein was $3.1 \pm 0.2$ and $265 \pm 19 \mathrm{nM}$, respectively.

Effects of factor Xa on cell number and protein content. The effects of factor $\mathrm{Xa}$ on cell number and protein content were next evaluated. As shown in Table I, factor Xa, FCS and PDGF increased the number and protein content of the cell. Both increases induced by factor $\mathrm{Xa}$ were blocked by mAb5224 and rTAP. The mitogenic effect was also assessed by flow cytometry. As shown in Fig. $5 A$, 95\% of quiescent VSMC were in the growth-arrested $\left(\mathrm{Go} / \mathrm{G}_{1}\right)$ phase of the cell cycle, whereas after $20 \mathrm{~h}$ stimulation with factor $\mathrm{Xa}, 43 \%$ of the VSMC were in the S phase and $12 \%$ in the $\mathrm{G}_{2} / \mathrm{M}$ phase of the cell cycle (Fig. 5 B). mAb5224 and anti-human PDGF-AB antibody markedly inhibited this response (Fig. 5, $C$ and $D$ ).

Activation of MAPK by factor Xa. DNA synthesis and thus cell proliferation were usually preceded by MAPK activation. We therefore checked to see whether or not factor Xa activated MAPK. Western blot analysis of VSMC lysates with a $\mathrm{mAb}$ against the 42- and 44-kD MAPK confirmed that both isoforms were present in cultured VSMC from WKY. Activa- 
Table I. Stimulation of Cell Growth and Protein Synthesis by Exposure to Factor Xa, FCS, and PDGF

\begin{tabular}{|c|c|c|c|}
\hline \multirow[b]{2}{*}{ Treatments } & \multicolumn{2}{|c|}{ Cell number (fold) } & \multirow{2}{*}{$\frac{\begin{array}{c}\text { Protein content } \\
\text { (fold) }\end{array}}{\text { Day } 1}$} \\
\hline & Day 1 & Day 2 & \\
\hline Resting & $1.00 \pm 0.09$ & $1.32 \pm 0.17$ & $1.00 \pm 0.08$ \\
\hline Factor $\mathrm{Xa}$ & $1.85 \pm 0.02 *$ & $2.30 \pm 0.17 *$ & $2.58 \pm 0.21 *$ \\
\hline $\mathrm{mAb} 5224+$ Factor Xa & $1.16 \pm 0.07^{\ddagger}$ & $1.49 \pm 0.19^{\S}$ & $1.28 \pm 0.17^{\ddagger}$ \\
\hline rTAP + Factor Xa & $1.05 \pm 0.02^{\ddagger}$ & $1.25 \pm 0.10^{\ddagger}$ & $1.15 \pm 0.09^{\ddagger}$ \\
\hline FCS & $2.11 \pm 0.08^{*}$ & $3.60 \pm 0.14 *$ & $4.42 \pm 0.26^{*}$ \\
\hline PDGF & $1.90 \pm 0.10^{*}$ & $2.50 \pm 0.20 *$ & $2.51 \pm 0.26^{*}$ \\
\hline
\end{tabular}

Quiescent cells were treated with factor Xa (6 nM), FCS (10\%) or PDGF $(2 \mathrm{ng} / \mathrm{ml})$ in the absence or presence of mAb5224 $(2.5 \mu \mathrm{g} / \mathrm{ml})$ or rTAP $(10 \mathrm{nM})$ for 1 or $2 \mathrm{~d}$. After specific times, the cells were washed and the cell number or the radioactivity counted. The radioactivity of $\left[{ }^{3} \mathrm{H}\right]$ leucine incorporation into resting VSMC was $349 \pm 35 \mathrm{dmp} / \mathrm{mg}$ protein. Data are the mean $\pm \operatorname{SEM}(n=6$, for quadruplicate samples). $* P<$ 0.001 as compared with the resting cells. ${ }^{\ddagger} P<0.001$; and ${ }^{\S} P<0.01$ as compared with the factor Xa-treated cells.

tion of both forms was therefore examined. Activation of MAPK requires phosphorylation of both tyrosine and threonine residues (25); thus tyrosine phosphorylation was measured as the sign of MAPK activation. Cell lysates were immunoprecipitated with anti-mouse MAPK 1 (erk 1) and anti-MAPK 2 (erk 2) antibodies which were further treated with anti-phosphotyrosine antibody (Py20) in Western blotting. As shown in Fig. 6 $A$, tyrosine phosphorylation in both 42 - and $44-\mathrm{kD}$ MAPK was observed 2 min after stimulation, reaching a peak at $10 \mathrm{~min}$, and decreasing gradually thereafter. Consistent with this result, increase in MAPK activity as a function of time was observed (Fig. $6 \mathrm{C}$ ). The tyrosine phosphorylation was inhibited by concomitant treatment of VSMC with mAb5224 $(2.5 \mu \mathrm{g} /$ $\mathrm{ml})$, PMSF $(30 \mu \mathrm{M})$, anti-human PDGF-AB antibody $(5 \mu \mathrm{g} /$ $\mathrm{ml})$, lavendustin A $(30 \mathrm{nM})$ or tyrphostin $9(0.1 \mu \mathrm{M})($ Fig. $6 B)$. It was also inhibited, as expected, by benzamidine $(100 \mu \mathrm{M})$ and TLCK (10 mM) (data not shown). The MAPK activity was also increased $4.5 \pm 0.4$-fold in VSMC challenged with PDGF $(2 \mathrm{ng} / \mathrm{ml})$ for $10 \mathrm{~min}$.

Effect of factor Xa on the production of c-Fos and c-Jun. Activated MAPK have been shown to convert certain transcription factors such as c-Fos and c-Jun, into active forms, which in turn activate transcription (26-28). Therefore, the production of the c-Fos and c-Jun proteins was checked as a sign of activation. As shown in Fig. 7, factor $\mathrm{Xa}$ induced 3.20 \pm 0.45 - and 4.80 \pm 0.75 -fold increase in c-Fos and c-Jun production, respectively. In the presence of mAb5224 $(2.5 \mu \mathrm{g} / \mathrm{ml})$, PMSF $(30 \mu \mathrm{M})$ or lavendustin A $(30 \mathrm{nM})$, this production was completely inhibited (Fig. $7 \mathrm{C}$ ). Benzamidine $(100 \mu \mathrm{M})$ and TLCK $(10 \mathrm{mM})$ also inhibited the production completely (data not shown).

Effect of factor Xa on the formation of inositol phosphates and intracellular free $\mathrm{Ca}^{2+}$ concentration. One of the pathways that activate MAPK is the activation of phospholipase C. We therefore checked whether or not factor $\mathrm{Xa}$ induced $\left[{ }^{3} \mathrm{H}\right]$ inositol phosphate (IP) accumulation and $\mathrm{Ca}^{2+}$ mobilization, both a sign of phospholipase $\mathrm{C}$ activation. The results indicated that factor $\mathrm{Xa}(6 \mathrm{nM})$ showed no effect, while thrombin $(1 \mathrm{U} / \mathrm{ml})$ stimulated $2.0 \pm 0.1$-fold increase in [ $\left.{ }^{3} \mathrm{H}\right] \mathrm{IP}(n=4)$. Similar effects of the factors on intracellular free $\mathrm{Ca}^{2+}$ concen-

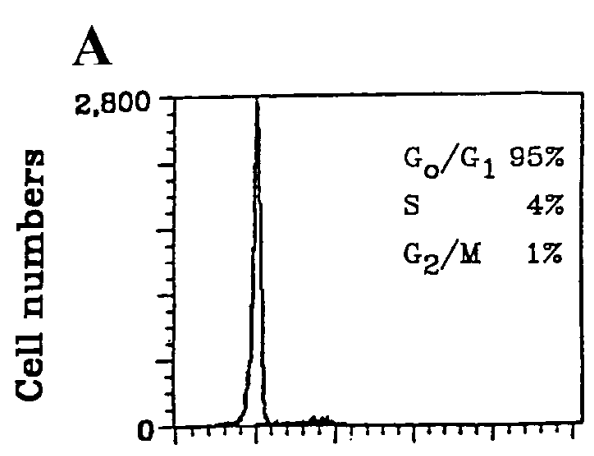

B

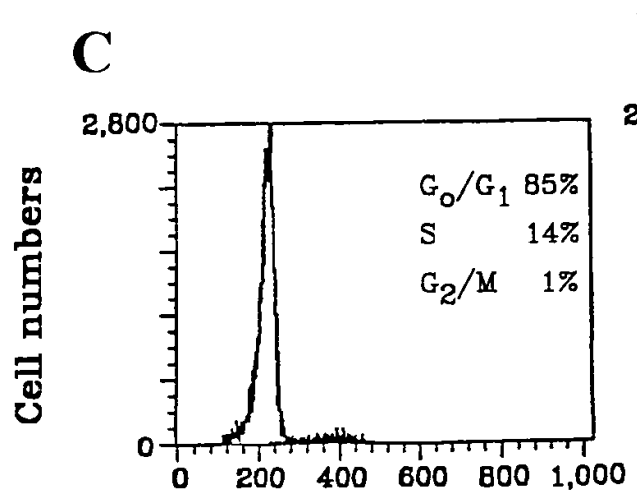

D
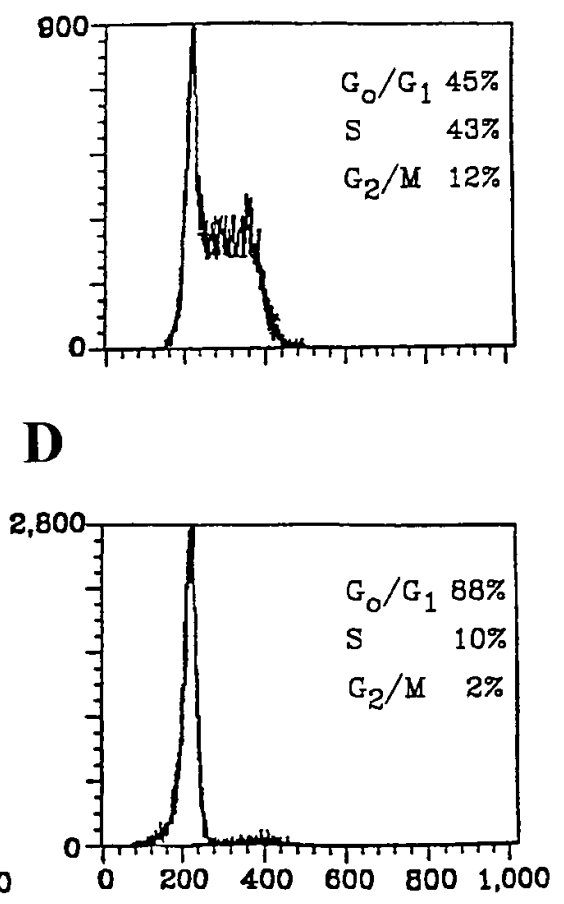

\section{Relative DNA content}

Figure 5. Effect of factor Xa on cell cycle progression of VSMC. Quiescent cells were stimulated with factor $\mathrm{Xa}(6 \mathrm{nM})$ in the absence $(B$, control) or presence of mAb5224 $(2.5 \mu \mathrm{g} / \mathrm{ml}, C)$ or anti-human PDGF-AB antibody $(5 \mu \mathrm{g} / \mathrm{ml}, D)$ for $20 \mathrm{~h}$. $A$ indicates the DNA content for the untreated resting cells. 


\section{A}

$$
\underset{0}{=} \underset{2}{=} \underset{5}{=} \underset{10}{=}=\underset{30}{=}=\underset{60}{=}=\frac{\mathrm{p} 42}{240}
$$

\section{B}

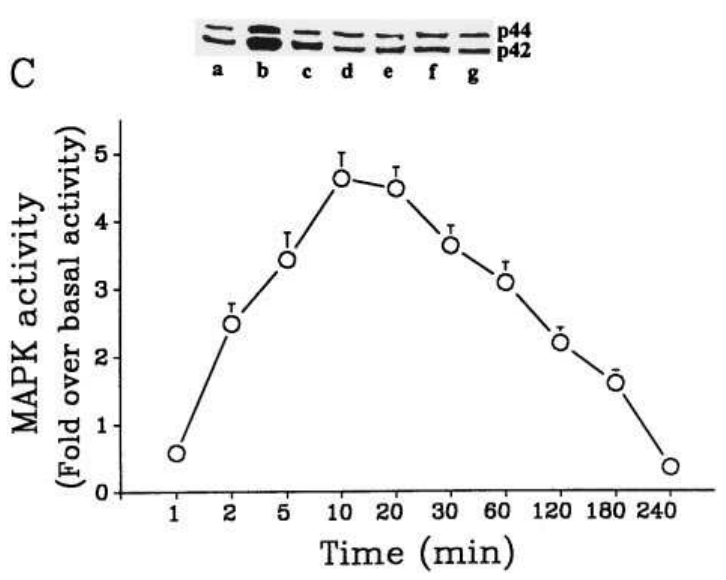

Figure 6. Kinetics of tyrosine phosphorylation and activation of MAPK in VSMC stimulated by factor Xa. Quiescent cells were stimulated with factor $\mathrm{Xa}(6 \mathrm{nM})$ for the indicated time periods $(A)$ or for $10 \mathrm{~min}(B)$ in the absence (lane $b$, control) or presence of mAb5224 $(2.5 \mu \mathrm{g} / \mathrm{ml}$, lane $c)$, PMSF (30 $\mu \mathrm{M}$, lane $d)$, anti-human PDGF-AB antibody $(5 \mu \mathrm{g} / \mathrm{ml}$, lane $e)$, lavendustin A ( $30 \mathrm{nM}$, lane $f$ ) or tyrphostin $9(0.1 \mu \mathrm{M}$, lane $g)$. Immunoprecipitation of cell lysates with antirat MAPK antibody and Western blotting analysis with anti-phosphotyrosine antibody (Py20) were performed. $0 \mathrm{~min}$ in $A$ and lane $a$ in $B$ indicate tyrosine phosphorylation of 42 - and $44-\mathrm{kD}$ MAPK in resting VSMC. In $C$, quiescent cells were stimulated with factor Xa (6 $\mathrm{nM}$ ) for the indicated time periods. The MAPK activity in the cell lysate was determined as described in Methods. Basal MAPK activity of VSMC was $550 \pm 30 \mathrm{pmol} / \mathrm{min}$ per $\mathrm{mg}$ protein. Data are the mean $\pm \operatorname{SEM}(n=6)$.

tration in VSMC were observed: the free $\mathrm{Ca}^{2+}$ concentration in resting VSMC was measured to be $106 \pm 14 \mathrm{nM}(n=4)$, and this level was altered little when factor Xa was added; whereas a $177 \pm 26 \mathrm{nM}(n=4)$ increase over the basal level was observed when thrombin $(1 \mathrm{U} / \mathrm{ml})$ was present.

Effects of factor Xa on Ras-GTP accumulation and p $74^{\text {raf- } 1}$ activation. Another pathway that would activate MAPK is via activation of MAPK kinase (MAPKK, MEK), a direct upstream activator of MAPK, and this pathway involves $\mathrm{p} 21^{\text {ras }}$ and $\mathrm{p} 74^{\mathrm{raf}-1}(29)$. We therefore measured the GTP form of Ras and Raf-1 activity in VSMC to see whether factor Xa-stimulated MAPK activation was achieved via activation of Ras and Raf. In quiescent VSMC, endogenous $\mathrm{p} 21^{\text {ras }}$ was almost entirely in the inactive form. The ratio of GTP/GTP+GDP bound to p $21^{\text {ras }}$ was thus measured and found to be markedly increased by the presence of factor Xa (Fig. $8 \mathrm{~A}$ ). On the other hand, p74 raf-1 kinase activity in unstimulated VSMC was $350 \pm 39 \mathrm{pmol} / \mathrm{min}$ per $\mathrm{mg}$ protein and increased by $79 \pm 11 \%$ when factor Xa was added (Fig. 8 B). A 90 $13 \%$ increase in Raf-1 kinase activity was observed when exogenous PDGF (2 $\mathrm{ng} / \mathrm{ml}$ ) was added. Both Ras-GTP accumulation and p74 ${ }^{\text {raf-1 }}$ activation induced by factor Xa were inhibited by mAb5224, PMSF, lavendustin A, tyrphostin 9, or anti-human PDGF-AB antibody (Fig. 8). Again, benzamidine $(100 \mu \mathrm{M})$ or TLCK (10

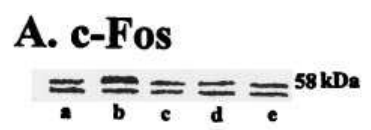

B. c-Jun

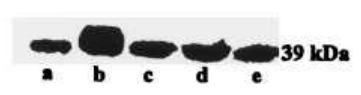

C.

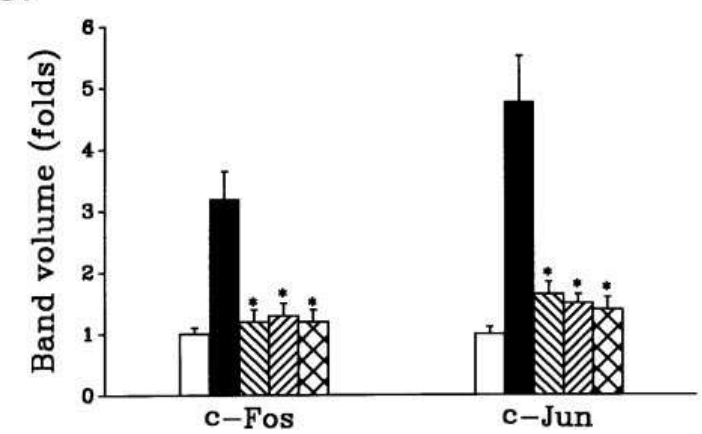

Figure 7. Accumulation of c-Fos and c-Jun in VSMC treated with factor Xa, and its inhibition by mAb5224, PMSF and lavendustin A. Cells were stimulated with factor Xa (6 nM) for $90 \mathrm{~min}$ (c-Fos) or 240 min (c-Jun) in the absence (lane $b$ and $\mathbf{\square}$, control) or presence of $\mathrm{mAb} 5224(2.5 \mu \mathrm{g} / \mathrm{ml}$, lane $c$ and $\mathbb{\mathbb { N }})$, PMSF (30 $\mu \mathrm{M}$, lane $d$ and $\mathbb{R})$ or lavendustin A ( $30 \mathrm{nM}$, lane $e$ and $\otimes$ ). The c-Fos and c-Jun accumulations were obtained by Western blotting as described in Methods. Lane $a$ in both panels indicates the c-Fos and c-Jun of untreated cells.

$\mathrm{mM}$ ) almost completely inhibited factor Xa-induced p $74^{\mathrm{raf}-1} \mathrm{ac}-$ tivity $(3 \pm 2$ and $7 \pm 3 \%$ increases over basal activity, respectively).

Effect of factor Xa on PDGF release. The above observation that the effect of factor Xa was blocked by anti-human PDGF-AB antibody suggested that PDGF might be involved. Therefore, the kinetic of PDGF production was measured. The PDGF content in the conditioned medium derived from resting VSMC was $0.20 \pm 0.07 \mathrm{ng} / 10^{6}$ cells. The addition of factor Xa seemed to enhance the release of PDGF: the amount was significantly increased in $1 \mathrm{~min}$ after stimulation and reached a peak at $180 \mathrm{~min}$ (Fig. $9 \mathrm{~A}$ ). This factor Xa-induced PDGF release was not blocked by concomitant treatments of VSMC with actinomycin D or cycloheximide. On the other hand, mAb5224 markedly inhibited factor Xa-induced PDGF release from VSMC (Fig. $9 B$ ).

\section{Discussion}

Coagulation protease, locally generated by limited proteolysis, interacts with vascular cell membrane receptors to trigger a panoply of intracellular signaling events, which manifest early mechanisms of cell activation, cell adherence and intracellular communication, and modulation of gene expression, culminating in proliferation of normal and malignant cells. Although factor Xa, the activated form of factor X, the vitamin K-dependent coagulation zymogen, has been known to influence such cellular effector functions, the role of and the cellular mechanism induced by factor Xa in VSMC proliferation are largely unknown. We showed here that factor $\mathrm{Xa}$ is a progression fac- 


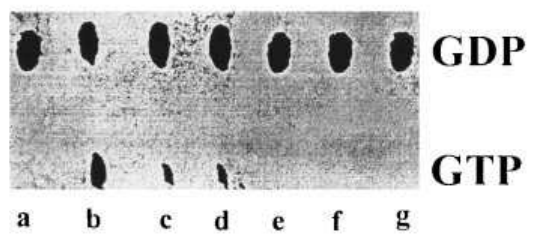

B

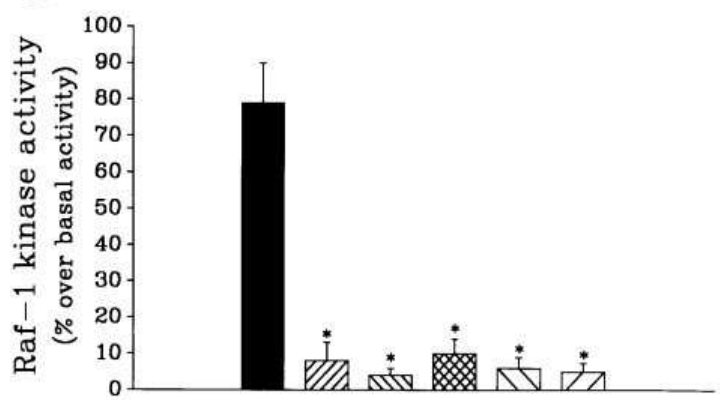

Figure 8. Activation of $\mathrm{p} 21^{\text {ras }}(A)$ and $\mathrm{p} 74^{\mathrm{raf}-1}(B)$ by factor Xa in VSMC. $(A)$ Quiescent cells labeled with $\left[{ }^{32} \mathrm{P}\right]$ phosphorus were incubated with factor Xa $(6 \mathrm{nM})$ in the absence (lane $b$, control) or presence of mAb5224 $(2.5 \mu \mathrm{g} / \mathrm{ml}$, lane $c)$, PMSF ( $30 \mu \mathrm{M}$, lane $d)$, antihuman PDGF-AB antibody $(5 \mu \mathrm{g} / \mathrm{ml}$, lane $e)$, lavendustin A (30 nM, lane $f)$ or tyrphostin $9(0.1 \mu \mathrm{M}$, lane $g)$ for $2 \mathrm{~min}$. Labeling of the cells and analysis of Ras-bound GTP and GDP were done as described in Methods. Lane a indicates the Ras-bound GTP and GDP content in untreated VSMC. $(B)$ Cells were treated with factor Xa $(6 \mathrm{nM})$ in the absence (control, $\mathbf{\square})$ or presence of mAb5224 $(2.5 \mu \mathrm{g} / \mathrm{ml}, \mathbb{R})$ ), PMSF $(30 \mu \mathrm{M}, \mathbb{N})$, anti-human PDGF-AB antibody $(5 \mu \mathrm{g} / \mathrm{ml}$, lavendustin $\mathrm{A}(30 \mathrm{nM}, \mathbb{\nabla})$, or tyrphostin $9(0.1 \mu \mathrm{M}, \mathbb{Z})$ for $2 \mathrm{~min}$. Raf-1 was immunoprecipitated with a $\mathrm{COOH}$-terminal-specific polyclonal antibody and its activity determined. Raf- 1 activity of unstimulated VSMC was $350 \pm 39 \mathrm{pmol} / \mathrm{min}$ per $\mathrm{mg}$ protein. Data are presented as the mean $\pm \operatorname{SEM}(n=6) . * P<0.001$ as compared with the control.

tor for proliferation of VSMC: it induced protein and DNA synthesis, increased cell number, and promoted cell cycle progression in cultured VSMC. As discussed below, such effects of factor Xa are an indirect one: it stimulates VSMC to release PDGF, that activates the PGDF receptor tyrosine kinase pathway, leading eventually to cell growth.

First, the possibility that such phenomena are the results of contaminating thrombin, also a coagulation enzyme and a well-established promoter of VSMC proliferation in vitro (30), has been ruled out results of tests with mAb5224 and hirudin. The observation that factor Xa-induced VSMC proliferation is dependent on its serine protease activity is supported by the results of experiments with serine protease inhibitors, especially with benzamidine, TAP anticoagulant, and TLCK, which are specific inhibitors of factor Xa active site. The zymogen, factor $\mathrm{X}$, the precursor of $\mathrm{Xa}$, did not stimulate VSMC proliferation.

Some proteins, like factor $\mathrm{X}$, of the coagulation cascade contain EGF-like domains $(31,32)$. Among them, protein $\mathrm{S}$

Figure 10. A diagram of probable activation steps induced by factor $\mathrm{Xa}$. Factor Xa, with its serine protease activity, somehow acts on the VSMC to stimulate the release of PDGF, that interacts with the receptor tyrosine kinase (R-TyK) to activate the pathway.
A

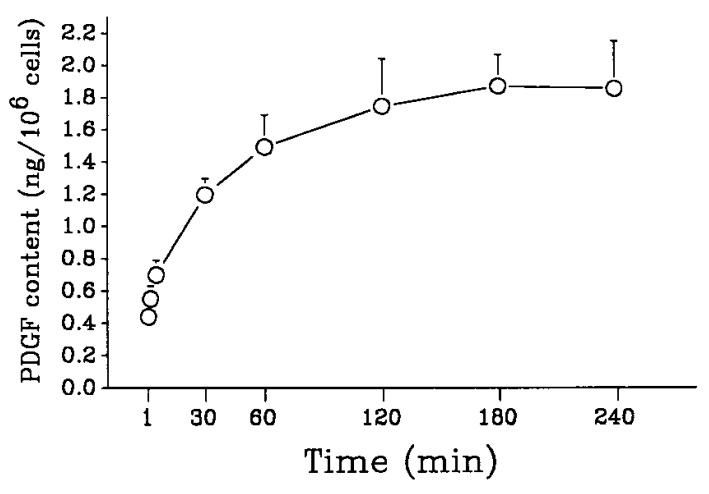

$\mathrm{B}$

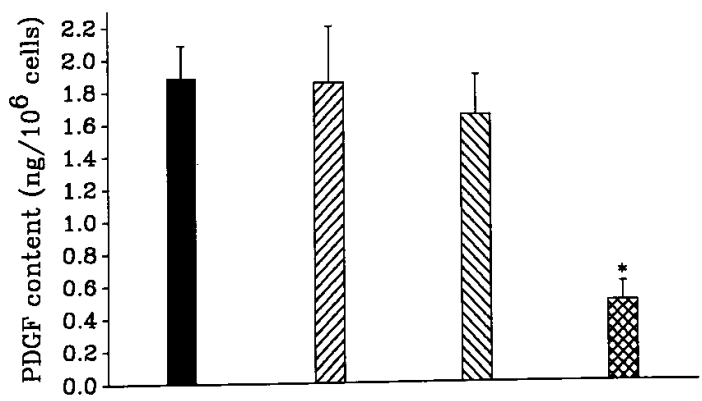

Figure 9. Stimulation of PDGF release in VSMC treated with factor $\mathrm{Xa}$, and its inhibition by actinomycin $\mathrm{D}$, cycloheximide and $\mathrm{mAb5224}$. Cells were treated with factor Xa $(6 \mathrm{nM})$ for the indicated times $(A)$ or for $180 \mathrm{~min}(B)$ in the absence (control, $\mathbf{\square})$ or presence

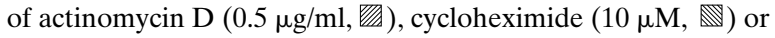
$\mathrm{mAb} 5224(2.5 \mu \mathrm{g} / \mathrm{ml}$, $)$. The PDGF content in the conditioned medium from resting VSMC was $0.20 \pm 0.07 \mathrm{ng} / 10^{6}$ cells. Data are presented as the mean $\pm \operatorname{SEM}(n=6-8) . * P<0.001$ as compared to the control.

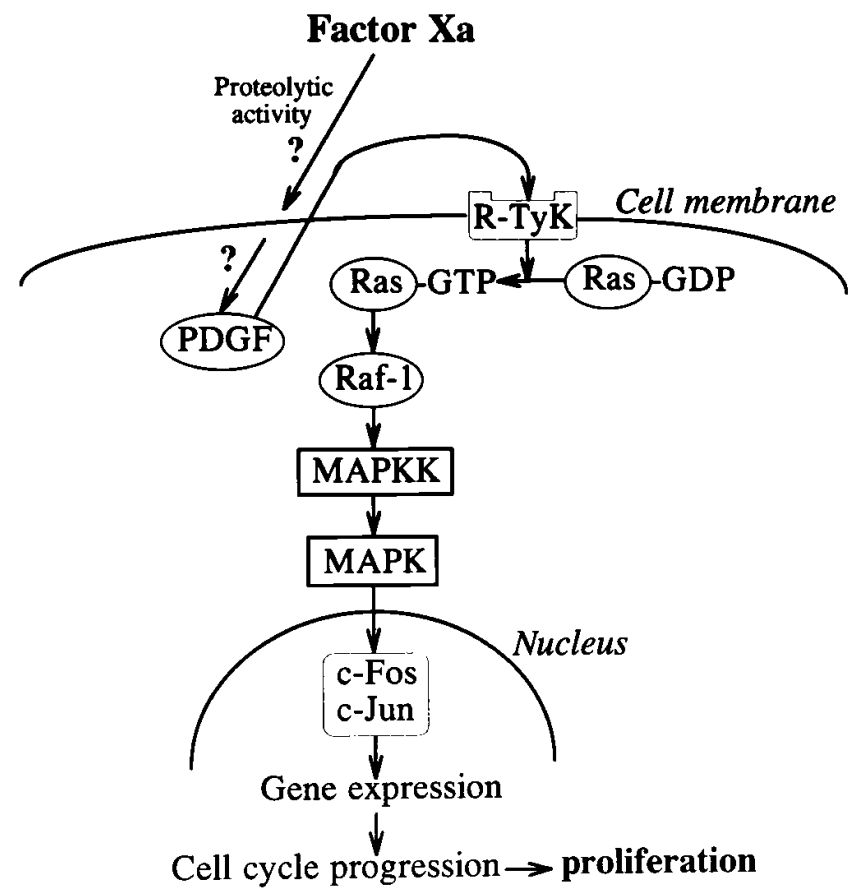


markedly stimulates VSMC proliferation but factors VII and IX and protein C do not (13). Addition of a monoclonal antibody (mAb41) against the epitopes of the third and fourth EGF-like domains of protein $\mathrm{S}$ abolishes its mitogenic activity, suggesting that the EGF-like domains are the active mitogenic sites (13). However, despite considerable sequence similarities between these coagulation factors, not all are mitogenic, suggesting that the presence of an EGF-like domain alone does not necessarily confer mitogenic activity. Factor $\mathrm{X}$ contains EGF-like domains but does not stimulate VSMC proliferation, implying that factor Xa-induced VSMC proliferation is probably not mediated by its EGF-like domains. This conclusion is supported by the observation that, selective inhibitors of the PDGF receptor tyrosine kinase, such as tyrphostin 9 (33), inhibited PDGF- and factor Xa-induced DNA synthesis but not that induced by EGF. As shown earlier, the action of factor Xa is inhibited by mAb5224, benzamidine, rTAP, and TLCK, all of which act on the active site, i.e., the serine protease activity, and therefore, VSMC proliferation appears to be mediated through this activity.

One of the action of factor Xa on VSMC is the activation of MAPK, which are a family of kinases that are well characterized intracellular mediators of cell proliferation $(26,29)$. They are activated by various growth factors such as thrombin and angiotensin II $(30,34)$. We have shown here that factor Xa activates the 42- and 44-kD MAPK as a function of time and concentration, and this activation is accompanied by tyrosine phosphorylation, which is a part of the established mechanism for the activation of MAPK $(26,29)$. As far as we know, this is the first demonstration that factor Xa induces tyrosine phosphorylation, which signifies the activation of MAPK in rat VSMC. The activated MAPK, as we showed, increases c-Fos and c-Jun in VSMC, and such increase is completely blocked by mAb5224, PMSF, lavendustin A, benzamidine and TLCK. Recent studies indicate that extracellular signals cause cell proliferation by modulating transcription factor activity in the nucleus via protein phosphorylation cascades (35), and certain transcription factors, such as c-Fos and c-Jun, are substrates for MAPK (26). Therefore, it seems that the activation of MAPK by factor Xa leads to phosphorylation of the transcription factors that, in turn, lead to the expression of genes for DNA synthesis and cell proliferation.

The next question is what pathway Xa induces for the activation of MAPK. Stimulation of phosphoinositide hydrolysis produces two second messengers, diacylglycerol and $\mathrm{IP}_{3}$. The former is known to activate protein kinase $\mathrm{C}$ (PKC), and the latter release of $\mathrm{Ca}^{2+}$ from the intracellular storage. The activation of PKC and increase of intracellular $\mathrm{Ca}^{2+}$ appear to account for most of the early proliferative events (36). Thrombin, angiotensin II and phorbol ester stimulate PKC in VSMC also induce tyrosine phosphorylation and MAPK activity in the cell $(37,38)$. Since factor $\mathrm{Xa}$, increases neither $\left[{ }^{3} \mathrm{H}\right]$ inositol phosphate formation nor intracellular $\mathrm{Ca}^{2+}$ concentration, the MAPK activation is not mediated by G-protein-coupled phosphoinositide hydrolysis. This is consistent with the recent finding that cloned factor Xa receptor, EPR-1, does not belong to the superfamily of G-protein-coupled receptors (39).

Another pathway that activates MAPK involves the RasRaf-1-MAPKK activation initiated by activation of tyrosine kinase receptors. In the presence of factor $\mathrm{Xa}$, both $\mathrm{Ras}$ and Raf-1 are indeed activated, and this activation was shown again to be blocked by PMSF, mAb5224, lavendustin A, tyr- phostin 9, benzamidine, and TLCK. Thus, factor Xa-stimulated MAPK activity appears to be mediated by PDGF receptor tyrosine kinase and serine protease activity of factor $\mathrm{Xa}$ is essential for the mitogenic activity. These results also imply that the mitogenic effect of factor Xa is mediated by a PDGFlike activity, and the results of anti-human PDGF-AB antibody that inhibits all factor Xa-induced phenomena indicate that factor Xa might stimulate the release of PDGF. Indeed, a direct measurement indicates the release of PDGF from factor Xa-challenged VSMC. The release of PDGF from VSMC was inhibited by mAb5224 but not by actinomycin D or cycloheximide, indicating that Xa stimulates VSMC to release PDGF and that the release does not require RNA or protein synthesis.

In summary, as shown in Fig. 10: factor Xa, via its serine protease activity, somehow stimulates the release of preexisting PDGF from VSMC; the PDGF in turn activates MAPK through the receptor tyrosine kinase-Ras-Raf-1 pathway, causing phosphorylation of transcription factors; which then induce gene expression, leading to DNA synthesis and the growth of the cell.

Intimal VSMC hyperplasia is the primary cause of vascular reocclusion and restenosis after angioplasty $(5,40)$. If the endothelial cell barrier in vivo is altered, the factor Xa-mediated VSMC mitogenesis that we observed in vitro could contribute, after angioplasty, to the high rate of arterial restenosis and even to atherogenesis.

\section{Acknowledgments}

This work was supported by research grants, NSC 85-2331-B-002-297 M25 (to F.N. Ko) and NSC 85-2331-B182-081 (to J.T. Ou), from the National Science Council, Executive Yuan, Republic of China, and CMRP 583 (to J.T. Ou) from Chang Gung Medical Research Foundation.

\section{References}

1. Ross, R. 1986. The pathogenesis of atherosclerosis: an update. N. Engl. J. Med. 314:488-500.

2. Ross, R., H. Masuda, and E.W. Raines. 1990. Cellular interactions, growth factors and smooth muscle cell proliferation in atherogenesis. Ann. NY Acad. Sci. 598:102-112.

3. Folkow, B. 1978. Cardiovascular structural adaptation: its role in the initiation and maintenance of primary hypertension. The fourth Volhard lecture. Clin. Sci. Mol. Med. 55(Suppl.):3S-22S.

4. Owens, G.K., and S.M. Schwartz. 1982. Alterations in vascular smooth muscle mass in the spontaneously hypertensive rat: role of cellular hypertrophy, hyperpoloidy, and hyperplasia. Circ. Res. 51:280-289.

5. Ip, J.H., V. Fuster, L. Badimon, J. Badimon, M.B. Taubman, and J.H. Chesebro. 1990. Syndromes of accelerated atherosclerosis: role of vascular injury and smooth muscle cell proliferation. J. Am. Coll. Cardiol. 15:1667-1687.

6. Uehara, Y., T. Ishimitsu, K. Kimura, M. Ishii, T. Ikeda, and T. Sugimoto. 1988. Regulatory effects of eicosanoids on thymidine uptake by vascular smooth muscle cells of rats. Prostaglandins. 36:847-857.

7. Majack, R.A. 1987. Beta-type transforming growth factor specifies organizational behavior in vascular smooth muscle cell cultures. J. Cell Biol. 105 $465-471$.

8. Hirata, Y., Y. Takagi, Y. Fukuda, and F. Marumo. 1989. Endothelin is a potent mitogen for rat vascular smooth muscle cells. Atherosclerosis. 78:225228.

9. Bini, A., J.F. Fenoglio, J. Sobel, J. Owen, and K. Kaplan. 1985. Fibrin and fibrin related antigens in human thrombi and atherosclerotic lesions. Thromb. Haemostasis. 54:165.

10. Woolf, N. 1978. Thrombosis and atherosclerosis. Br. Med. Bull. 34:137142.

11. Gunnar, F. 1995. Thrombin and proliferation of vascular smooth muscle cells. Circ. Res. 77:645-650.

12. Gajdusek, C., S. Carbon, R. Ross, P. Nawroth, and D. Stern. 1986. Activation of coagulation releases endothelial cell mitogens. J. Cell Biol. 103:419428 . 
13. Gasic, G.P., C.P. Arenas, T.B. Gasic, and G.J. Gasic. 1992. Coagulation factors $\mathrm{X}, \mathrm{Xa}$, and protein $\mathrm{S}$ as potent mitogens of cultured aortic smooth muscle cells. Proc. Natl. Acad. Sci. USA. 89:2317-2320.

14. Ross, R. 1971. The smooth muscle cell. II. Growth of smooth muscle in culture and formation of elastic fibers. J. Cell Biol. 50:172-186.

15. Ko, F.N., S.M. Yu, Y.F. Kang, and C.M. Teng. 1995. Characterization of the thromboxane (TP-) receptor subtype involved in proliferation in cultured vascular smooth muscle cells of rat. Br. J. Pharmacol. 116:1801-1808.

16. March, K.L., R.L. Wilensky, R.W. Roeske, and D.R. Hathaway. 1993. Effects of thiol protease inhibitors on cell cycle and proliferation of vascular smooth muscle cells in cultures. Circ. Res. 72:413-423.

17. Alexander, S.P.H., D.A. Kendall, and S.J. Hill. 1989. Differences in the adenosine receptors modulating inositol phosphates and cyclic AMP accumulation in mammalian cerebral cortex. Br. J. Pharmacol. 98:1241-1248.

18. Grynkiewicz, G., M. Poenie, and R.Y. Tsien. 1985. A new generation of $\mathrm{Ca}^{2+}$ indicators with improved fluorescence properties. J. Biol. Chem. 260: 3440-3450.

19. Morinelli, T.A., L.M. Zhang, W.H. Newman, and K.E. Mier. 1994. Thromboxane $\mathrm{A}_{2}$ /prostaglandin $\mathrm{H}_{2}$-stimulated mitogenesis of coronary artery smooth muscle cells involves activation of mitogen-activated protein kinase and $\mathrm{S}_{6}$ kinase. J. Biol. Chem. 269:5693-5698.

20. Erikson, A.K., D.M. Payne, P.A. Martino, A.J. Rossomando, J. Shabanowitz, M.J. Weber, D.F. Hunt, and T.W. Sturgill. 1990. Identification by mass spectrometry of threonine 97 in bovine myelin basic protein as a specific phosphorylation. J. Biol. Chem. 265:19728-19735.

21. Muroya, K., S. Hattori, and S. Nakamura. 1992. Nerve growth factor induces rapid accumulation of the GTP-bound form of $\mathrm{p} 21^{\text {ras }}$ in rat pheochromocytoma PC12 cells. Oncogene. 7:277-281.

22. Burgering, B.M.T., R.H. Medema, J.A. Maassen, M.L. van de Wetering, A.J. van der Eb, F. McCormik, and J.L. Bos. 1991. Insulin stimulation of gene expression mediated by $\mathrm{p} 21^{\text {ras }}$ activation. EMBO (Eur. Mol. Biol. Organ.) J. 10: 1103-1109.

23. Sozeri, O., K. Vollmer, M. Liyanage, D. Frith, G. Kour, G.E. Mark, and S. Stabel. 1992. Activation of the c-Raf protein kinase by protein kinase C phosphorylation. Oncogene. 7:2259-2261.

24. Kumar, R.K., R.A. Bennett, and A.R. Brody. 1988. A homologue of platelet-derived growth factor produced by rat alveolar macrophages. FASEB J. 2:2272-2277.

25. Thomas, G. 1992. MAP kinase by any other name smells just as sweet. Cell. 68:3-6.
26. Davis, R.J. 1993. The mitogen-activated protein kinase signal transduction pathway. J. Biol. Chem. 268:14553-14556.

27. Seth, A., F.A. Gonzalez, S. Gupta, D.L. Raden, and R.J. Davis. 1992. Signal transduction within the nucleus by mitogen-activated protein kinase. $J$. Biol. Chem. 267:24796-24804.

28. Baker, S.J., T.K. Kerppola, D. Luk, M.T. Vanderberg, D.R. Marshak, T. Curran, and C. Abate. 1992. Jun is phosphorylated by several protein kinases at the same sites that are modified in serum-stimulated fibroblasts. Mol. Cell Biol. 12:4694-4705.

29. Crews, G.M., and R.L. Erikson, 1993. Extracellular signals and reversible protein phosphorylation: What to Mek of it all. Cell. 74:215-217.

30. Fager, G. 1995. Thrombin and proliferation of vascular smooth muscle cells. Circ. Res. 77:645-650.

31. Dahlback, B., A. Lundwall, and J. Stenflo. 1986. Primary structure of bovine vitamin K-dependent protein S. Proc. Natl. Acad. Sci. USA. 83:41994203.

32. Furie, B., and B.C. Furie. 1988. The molecular basis of blood coagulation. Cell. 53:505-518

33. Levitzki, A., and C. Gilon. 1991. Tyrphostins as molecular tools and potential antiproliferative drugs. Trends Pharmacol. Sci. 12:171-174.

34. Schorb, W., G.W. Booz, D.E. Dostal, K.M. Conrad, K.C. Chang, and K.M. Baker. 1993. Angiotensin II is mitogen in neonatal rat cardiac fibroblasts. Circ. Res. 72:1245-1254.

35. Karin, M. 1992. Signal transduction from cell surface to nucleus in development and disease. FASEB J. 6:2581-2590.

36. Pouyssegur, J., and K. Seuwen. 1992. Transmembrane receptors and intracellular pathways that control cell proliferation. Annu. Rev. Physiol. 54:195210

37. Caramelo, C., K. Okada, D. Tsai, and R.W. Schrier. 1989. Phorbol esters and arginine vasopressin vascular smooth muscle cell activation. Am. J. Physiol. 256:F875-F881.

38. Granot, Y., E. Krikson, H. Fridman, V.V. Putten, B. Williams, R.W. Schrier, and J.L. Maller. 1993. Direct evidence for tyrosine and threonine phosphorylation and activation of mitogen-activated protein kinase by vasopression in cultured rat vascular smooth muscle cells. J. Biol. Chem. 268:9564-9569.

39. Altieri, D.C. 1995. Xa receptor EPR-1. FASEB J. 9:860-865.

40. Waller, B.F., C.A. Pinkerton, C.M. Orr, J.D. Slack, J.W. van Tassel, and T. Peters. 1991. Restenosis 1 to 24 months after clinically successful coronary balloon angioplasty: a necropsy study of 20 patients. J. Am. Coll. Cardiol. 17: 58B-70B 